\title{
Comparison of three hand dynamometers in relation to the accuracy and precision of the measurements
}

\author{
Comparação de três dinamômetros de preensão manual relacionados à exatidão \\ e precisão das medidas
}

Josária F. Amaral', Marcelly Mancini², José M. Novo Júnior',3

\begin{abstract}
Background: Given the variety of available hand-held dynamometers and their different handle shapes, reliability studies are needed. Objectives: To compare the accuracy and reliability between three different hand-held dynamometers and analyze the influence of their handles on grip strength. Methods: The tests were performed with the Jamar ${ }^{\circledR}$ dynamometer, the Takei ${ }^{\circledR}$ dynamometer and the EMG System Manual Transducer with modified handle. Eighteen healthy volunteers aged $20.0 \pm 1.3$ years without history of musculoskeletal disorders or trauma in the evaluated limbs were included. Data normality was tested using the Shapiro-Wilk test. To verify possible differences between the dynamometers, repeated measures ANOVA was administered, followed by Tukey post-hoc tests. Reliability between measurements was evaluated using intraclass correlation coefficient (ICC) and agreement was tested using Bland and Altman plots. The dynamometers calibration process was evaluated using linear regressions. Results: We observed statistically significant differences on the female group between the Jamar ${ }^{\circledR}$ and the Takei ${ }^{\oplus}$ dynamometers (females $p<0.001$ and males $p=0.022$ ) and the EMG System Manual Transducer (female $p<0.001$ and males $p=0.007$ ). However, the Take ${ }^{\circledR}$ dymamometer and the EMG System Manual Transducer were similar for both female $(p=0.161)$ and male groups $(p=0.850)$. Although acceptable values of intraclass correlation coefficients between measurements were identified, low agreement between the Jamar ${ }^{\circledR}$ dynamometer and all other instruments was found. Conclusions: The results demonstrated that there is an influence of the dynamometer's handle shapes on the measurements of grip strength. Furthermore, the results demonstrated the need for previous calibration of this type of instrument.
\end{abstract}

Keywords: dynamometer; grip strength; physical therapy.

\section{Resumo}

Contextualização: Dada a variedade de dinamômetros disponíveis para mensurar a força de preensão manual com diferentes formatos de empunhaduras, estudos de confiabilidade fazem-se necessários. Objetivos: Comparar a exatidão e a precisão das medidas de três dinamômetros distintos e analisar a influência do perfil de empunhadura de cada um. Métodos: Os testes foram realizados com os dinamômetros Jamar® ${ }^{\circledR}$, Take ${ }^{\circledR}$ e o Transdutor Manual EMG System com empunhadura modificada. Foram avaliados 18 voluntários saudáveis, com idade de $20 \pm 1,3$ anos, sem histórico de doença musculoesquelética ou traumas nos membros avaliados. A normalidade dos dados foi testada por meio do teste Shapiro-Wilk. Para verificar as possíveis diferenças entre as medições dos dinamômetros, aplicou-se uma ANOVA para medidas repetidas seguida do post-hoc de Tukey. A confiabilidade entre as medidas foi avaliada por meio do Coeficiente de Correlação Intraclasse (CCl), e a concordância foi testada utilizando o procedimento de Bland e Altman. Para o procedimento de calibração dos dinamômetros, procedeu-se à análise de regressão linear e de covariância. Resultados: Observou-se diferença estatisticamente significativa entre o dinamômetro Jamar ${ }^{\circledR}$ e os dinamômetros Takei (feminino $p<0,001$ e masculino $p=0,022$ ) e Transdutor (feminino $p<0,001$ e masculino $p=0,007)$. Todavia, Take ${ }^{\otimes}$ e Transdutor mostraram-se semelhantes para o grupo feminino $(p=0,161)$ e masculino $(p=0,850)$. Apesar de valores aceitáveis de correlação intraclasse entre as medidas, pode-se observar baixa concordância entre o dinamômetro Jamar ${ }^{\circledR}$ e dos demais instrumentos. Conclusões: Constatou-se a influência dos formatos das empunhaduras na medição da força muscular de preensão da mão como também a necessidade de calibração prévia desse tipo de instrumento.

Palavras-chave: dinamômetro; força da mão; fisioterapia

Received: 06/21/2011 - Revised: 09/14/2011 - Accepted: 01/12/2012

${ }_{1}$ Program of Master in Physical Education, School of Physical Education and Sports, Universidade Federal de Juiz de Fora (UFJF), Juiz de Fora, MG, Brazil

${ }^{2}$ Program of Tutorial Education, School of Physical Education and Sports, UFJF, Juiz de Fora, MG, Brazil

${ }^{3}$ Department of Physical Education and Human Motricity, Universidade Federal de São Carlos (UFSCar), São Carlos, SP, Brazil

Correspondence to: Josária Ferraz Amaral, Rua José Kneipp Filho, 38/303, Bairro São Pedro, CEP 36037-230, Juiz de Fora, MG, Brasil, e-mail: josaria_ferraz@hotmail.com 


\section{Introduction $: \therefore$.}

The assessment of grip strength by means of static muscle effort is easy to implement and requires the use of inexpensive and non-invasive instruments ${ }^{1}$. Due to the fact that upper limb function has a crucial role in the normal activities of daily life ${ }^{2,3}$, grip strength tests are important and support the diagnosis of diseases that are associated with the loss of muscle strength ${ }^{47}$, assists health professionals to interpret diagnostic results and to establish appropriate treatment goals. ${ }^{8}$ In addition to the assessment of disability ${ }^{9}$, response to treatment ${ }^{10}$ and evaluation of the ability of a patient to return to work ${ }^{11}$, these tests can also be used for assessments in various sports modalities ${ }^{12-14}$ and in tests for admission to different types of jobs ${ }^{15}$. Furthermore, grip strength measures are not only seen as an intrinsic measure of the hand strength or even limited to the assessment of the upper limbs. Because grip strength is necessary for the execution of many activities of daily living, the assessment of grip strength is often used in the clinical scenario as an indicator of the overall physical strength and health ${ }^{16}$.

There are a range of dynamometers available to objectively measure palmar grip strength. In these instruments, the thenar and hypothenar eminences are supported in the posterior aspect of the handle, inhibiting the action of the thumb, while the other fingers involve the anterior aspect of the handle ${ }^{17}$. The American Society of Hand Therapists describes specific procedures for the assessment of grip strength using the Jamar ${ }^{\circledR}$ dynamometer ${ }^{18}$. This instrument is the recommended and preferred tool, considered to be the gold standard for documenting grip strength ${ }^{19}$. For this reason, several recently published studies have focused on comparing newer tools, with different means of transmission and handle shapes, with the Jamar ${ }^{\circledR}$ analog dynamometer ${ }^{16,20-24}$.

In clinical practice, the use of methods and equipment with reliable measures is indispensable, since unreliable measures can compromise the evaluate of intervention programs. Therefore, reliability studies in rehabilitation are necessary to ensure that measurement errors are reduced and that changes occurring in the variable of interested are detected by the evaluation tool ${ }^{25}$.

Given the diversity of applications of grip strength tests, the need to evaluate the accuracy and precision of hand-held dynamometers with different handle shapes became evident. Thus, the primary goal of this study was to compare the accuracy and precision of three distinct hand-held dynamometers, named Jamar ${ }^{\circledR}$ (adjustable anatomical and rigid handle shape, hydraulic system, analogical display), Takei ${ }^{\circledR}$ (adjustable rectified and complacent handle shape, electro-mechanical system, digital display) and EMG Manual Transducer System of Brazil (modified anatomical handle shape ${ }^{26-28}$ and rigid, computerized, graphical interface). This was accomplished through linear modeling with the observation of calibration curves by the method of least squares, obtaining the $\mathrm{r}^{2}$ values, as well as analysis of variance and testing of the regression validity. The second objective was to compare the measures obtained with each dynamometer during static grip strength test and to evaluate the influences of each instrument handle shape on the recorded grip strength.

\section{Methods $:: \therefore$.}

\section{Participants}

Eighteen volunteers were assessed:, the average age was $20 \pm 1.3$ years, eight were male, they were all students and were invited to participate in the study forming a convenient sample. The exclusion criteria was: presence of musculoskeletal disease, injury, trauma or previous surgical intervention in the evaluated limbs. The volunteers were given detailed explanation of the study procedures and signed the free and informed consent approved by the Committee of Ethics in Research in Human at the Universidade Federal de Juiz de Fora (UFJF), Juiz de Fora, MG, Brazil, CEP/UFJF/1469.160.2008 Protocol UFJF, opinion $n^{\circ}$ 255/2008.

The sample size was calculated considering the equation demonstrated below, with $95 \%$ confidence interval $\left(Z_{\alpha / 2}=1.96\right)$, level of significance $\alpha=0.05$ and standard deviation of $10 \mathrm{kgf}$, as per the standard deviation obtained in a pilot study conducted prior to this study. The maximum desired error of the estimate $(E)$ was $5 \mathrm{kgf}$, which means that the inferences about the average of the studied sample were performed with a confidence interval of $1-\alpha \%$ and amplitude $\pm E$.

$\mathrm{n}=\left(\frac{Z_{\alpha / 2} \cdot \sigma}{E}\right)^{2}=\left(\frac{1.96 \cdot 10}{5}\right)^{2}=(3.92)^{2}=15.3664=16$ individuals Equation 1

In which:

$\mathrm{n}=$ number of subjects in the sample studied; $\mathrm{Z}_{\mathrm{a} / 2}=$ critical value; $\mathrm{s}=$ standard deviation; $E=$ maximal error of the estimate ${ }^{29,30}$.

\section{Material and procedures}

The analysis of precision and accuracy of measurements was conducted with the dynamometers Takei ${ }^{\circledR}$ (Figure 1a), Jamar $^{\circledR}$ (Figure 1b) and the Force Transducer's EMG System of Brazil that had a modified handle shape ${ }^{19}$ (Figure 1c), The dynamometer Jamar ${ }^{\circledR}$ had load limit of 0 to $90 \mathrm{kgf}$, analogic display, minimum reading of $1 \mathrm{kgf}$, rigid and adjustable anatomical handle, The dynamometer Takei ${ }^{\circledR}$ had load limit between 0 
and $100 \mathrm{kgf}$, digital display, minimum reading of $0.5 \mathrm{kgf}$, rectified adjustable and complacent handle. The Force transducer had load limit between 0 and $200 \mathrm{kgf}$, was computerized, with graphic display in monitor, minimum reading of $0.2 \mathrm{kgf}$, with modified rigid and adjustable handle.

Each dynamometer was statically calibrated with the gradual application of factual loads (washers) in the center of their handles, as recommended by Fess ${ }^{31}$ and the owner's manual ${ }^{32}$. The washers (average mass of $4.97 \pm 0.05 \mathrm{kgf}$ ) were added one by one until they reached the final load of $90 \mathrm{kgf}$, which coincidentally is the limit load of the Jamar ${ }^{\circledR}$ dynamometer, the lowest limit among the three analyzed dynamometers. Figure 2 shows a scheme of the placement of the dynamometer in the cargo system, where calibration readings after the addition of each load and stabilization of the system were performed. For each load increase, the strength value indicated on the dial of the dynamometer was registered.

The calibration curves were obtained based on the relationship between the application of loads and the reading of the dynamometers. These curves were constructed using simple linear regressions, adjusted by the method of minimal squares and analyzed with the following procedure: 1) confection of scatterplots dynamometer versus calibrator loads for each equipment; 2) adjustment of the respective linear regression models and determination of residues; 3) identification of the $\mathrm{r}^{2}$ and verification of normality and residues and 4) application of a covariance analysis model (ANCOVA), since the data provides Yd (load predicted value for a given dynamometer during the calibration process) and predictor $\mathrm{x}$ (the actual load value / washers). With this type of analysis, it was possible to model $Y_{d}$ as a linear function of $x$, with the coefficients of the regression line possibly ranging from equipment to equipment. In this way, the calibration was represented graphically by a line described by the equation $Y_{d}=a x+b$, where $Y_{d}$ was the value predicted for a load for a given dynamometer, $a$ was the angular coefficient of the equation of regression (calibration factor), $b$ was the linear coefficient of the regression equation and $\mathrm{x}$ (predictor) was the factual load value (washers).

At the end of the final loading (maximal load), the washers were gradually withdrawn from the system, one by one, so that the readings indicated on the dial of dynamometers were recorded again. The difference between the average errors of loading and withdrawal of loads enabled the calculation of hysteresis $(H)$ for each one of the dynamometers. As the Jamar ${ }^{\circledR}$ dynamometer readings are provided with an analogical display, the same evaluator was responsible for readings on this dynamometer to minimize error.

The assessment of grip strength was conducted after the calibration procedures. The use of the dynamometers by each
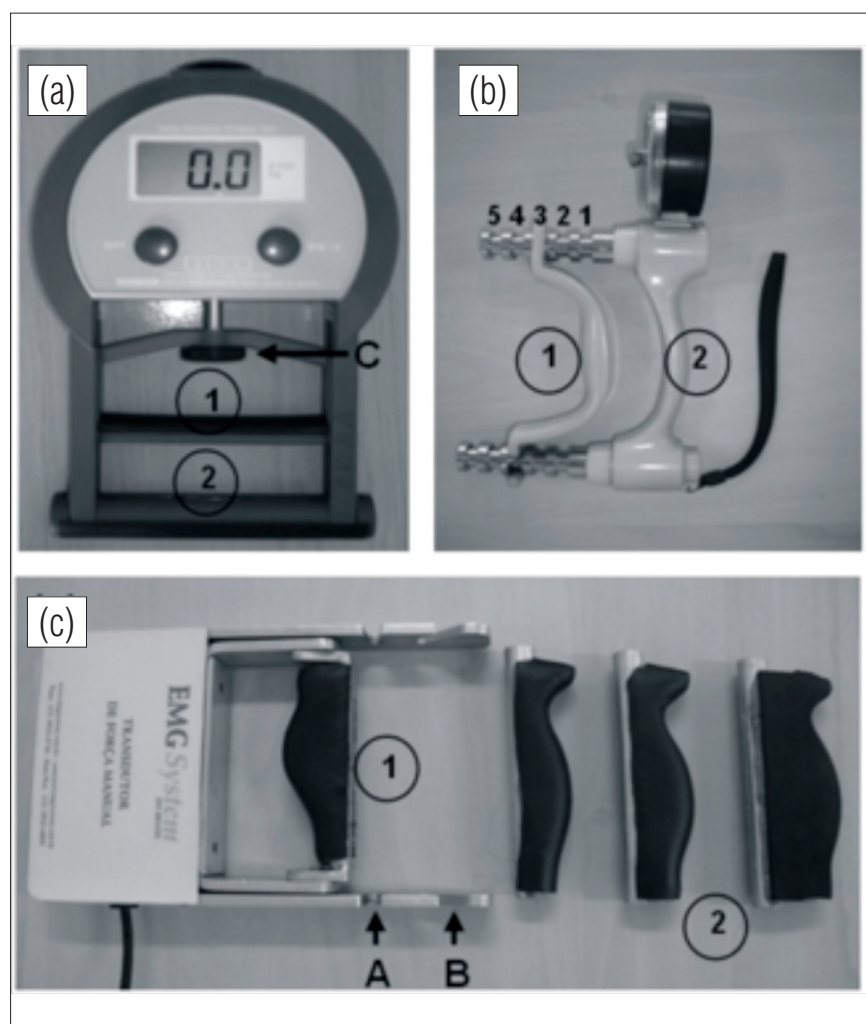

Figure 1. Characteristics of dynamometers: (a) Takei ${ }^{\circledR}$, model 5101 TKK, digital, non-static handle, rectified, with a mechanism for continued selection of positions (C); (b) Jamar ${ }^{\circledR}$, model 2A, hydraulic, analog, anatomical grip, 5 position options; (c) force transducer (EMG System, Brazil) digital, computerized, modified anatomical grip, with six position options (3 options in options A and 3 B). The grips are identified by anterior (1) and posterior (2) aspects that support the fingers and the thenar and hypothenar eminences.

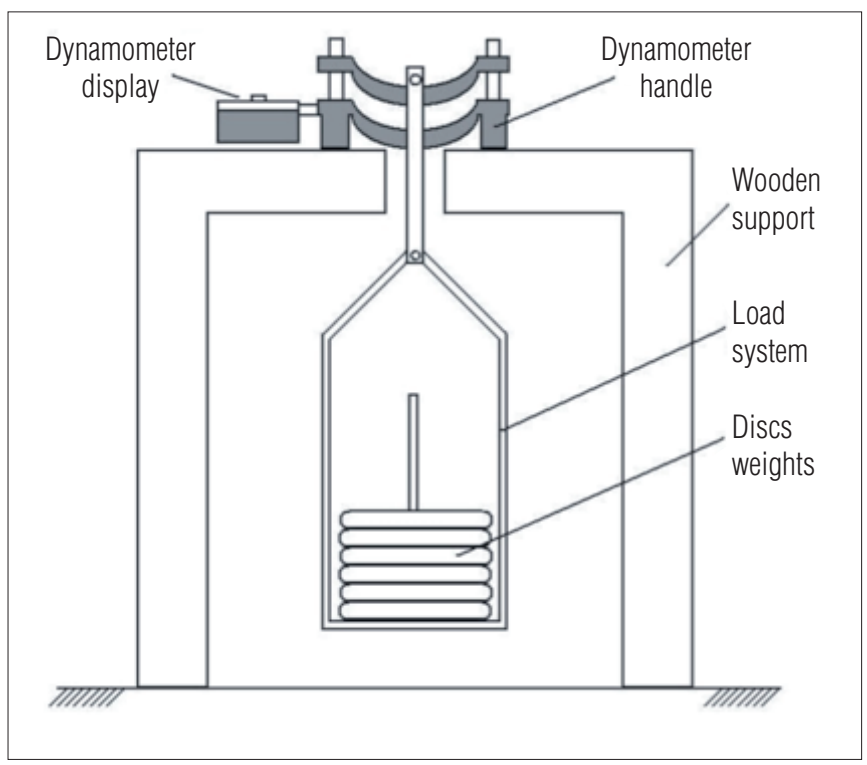

Figure 2. Dynamometers calibration system with the handle fixed on a wooden support to receive the load. The mass of the system that supported the load washers weighted $2.83 \mathrm{kgf}$. Illustrative image without scaling. 
volunteer was randomly assigned, respecting a minimum interval of $24 \mathrm{~h}$. The tests were performed individually, and the values recorded were not disclosed to the participants in order to avoid a competitive environment that could interfere with the interpretation of the data. Height and weight of the volunteers were recorded using a stadiometer and an analog scale model ASIMED.

Before the assessments of grip strength using each instrument specific warm up exercises were conducted. In each evaluation, three attempts of maximal isometric effort held for 6 seconds and with a range of 2 minutes between them were conducted in order to avoid accumulated muscle fatigue. The average of the three assessments was recorded. Muscle strength was alternately evaluated in both limbs. In all assessments, the standardized ASHT position ${ }^{18}$ in which the subject remained comfortably seated, shoulder adducted with no rotation, forearm flexed to 90 degrees and in neutral position, wrist position ranging from 0 and 30 degrees of extension was used. Therefore, volunteers involved the dynamometer's handle with the hand while the dynamometer was supported by the examiner.

To ensure that manual grip strength was produced from the participation of all fingers regardless of the size of the hand of volunteers, a criteria for choosing the size of the handle (width between the anterior and posterior aspects) was set. On the dynamometers, the support of the distal interphalangeal joint of the fifth finger over the anterior aspect of their handles ${ }^{33}$ was performed, in addition to the inhibition of the thumb action.

The volunteers received verbal guidance and encouragement "one, two, three, NOW! ... STRENGTH! ... STRENGTH! ... STRENGTH! ... THAT'S IT! ...RELAX ... “, issuing in a vigorously manner, in order to guarantee a maximum force during the 6 seconds of each test.

After each attempt, the force values showing on the displays of the dynamometers $\operatorname{Jamar}^{\circledR}$ (analogical) and Takei ${ }^{\circledR}$ (digital) were recorded for later statistical analysis. In the case of the Transducer, the values of maximum strength were recoded and the curves strength-time were identified and further analyzed in Matlab ${ }^{\circledR}$ software (license purchased through support of Fundação de Amparo a Pesquisa do Estado de Minas Gerais (FAPEMIG), Belo Horizonte, MG, Brazil, project APQ 01284/09).

\section{Data analysis}

The analysis of residues of the linear regression was performed to evaluate the assumption of normal distribution homocedasticity, guaranteeing the adequate interpretation of the ANCOVA. The ANCOVA was performed using the Matlab $^{\circledR}$ software for the identification of significant differences between the respective angular and linear coefficients of the calibration curves form each of the dynamometers.

Means and standard-deviations were calculated for the measurements of grip strength. To evaluate the possibility of using parametric tests, the Shapiro-Wilk test for normality was administered. Further, a repeated measures ANOVA analyses of variance, followed by Tukey post-hoc test were conducted to verify possible differences between the measurements taken by the three dynamometers.

The reliability between measures was evaluated using Intraclass Correlation Coefficient (ICC) calculated for the values of strength exhibited by the three dynamometers, as well as for the 95\% confidence interval (CI 95\%). Considering that the ICC, in general terms, is given by the relationship between group variance and total variance, the ICC Two-way fixed was used in this study. In this ICC, the factor 'subject' is random and the factor 'equipment' is fixed, with consistent estimator. Therefore, the measures of systematic error at the denominator were excluded ${ }^{34-36}$.

The agreement between two different dynamometers was tested using the procedure of Bland and Altman ${ }^{37}$, with limits of agreement defined as mean $\pm 1,96$ standard-deviations of the difference between the dynamometers (CI95\%). All statistical tests were performed in the programs Statistica 8.0 of Statsof $t^{\circledR}$ (USA), MedCalc ${ }^{\circledR}$, version 11.6.1 and Matlab ${ }^{\circledR}$ version 7.6. The level of significance adopted was $\mathrm{p}<0.05$.

\section{Results $: \because$ 。}

The procedure of calibration demonstrated the linearity of the curves of calibration $\left(\mathrm{Y}_{\text {jamar }}=1.0202 \mathrm{x}+1.7857\right.$; $\mathrm{Y}_{\text {takei }}=1.025 \mathrm{x}-$ 0.8526; $\left.\mathrm{Y}_{\text {transdutor }}=1.0412 \mathrm{x}+2.0915\right)$, all with $\mathrm{r}^{2}$ equal to 0,999 and residues with normal distribution. The inclination coefficients had $\mathrm{p}$ value, for Jamar ${ }^{\circledR}$, Takei ${ }^{\circledR}$ and the Transducer of 0.0485 ; 0.3854 and 0.0055 respectively. The respective median errors of indication, in other words, the differences between the mean value indicated by the instrument and the mean value indicated by the real load obtained were: 2.694; 0.316 and $3.949 \mathrm{kgf}$ for the dynamometers Jamar $^{\circledR}$, Takei ${ }^{\circledR}$ and Transducer, respectively (Figure 3). The values of hysteresis obtained for each device, which is the difference between the trend values (mean error) crescent and decrescent, respectively, to the administration and withdraw of the loads, were $H_{\text {jamar }}=2.08 \mathrm{kgf} ; H_{\text {takei }}=1.13 \mathrm{kgf}$ and $H_{\text {transducer }}=0.66 \mathrm{kgf}$.

In spite of the apparent similarity between the angular coefficients (slight difference in the second decimal place), it was necessary to analyze if in fact, the inclination between the straight lines were actually the same. The interaction equipments/calibrator (with two degrees of freedom) 
represents the significant difference between inclinations, for which the test of significance demonstrated the sum of the squares to be equal to 2.9; the quadratic mean equal to 1.4; with $\mathrm{F}=4.45$ and $\mathrm{p}=0.0168$. Nevertheless, the hypothesis that there were two similar and one dissimilar inclinations was tested. Through the test of multiple comparisons, it was found that there was no difference between the regression straight lines between the dynamometers Jamar ${ }^{\circledR}$ and Takei ${ }^{\circledR}$, with estimated difference of -0.0049 and $95 \% \mathrm{CI}$ of -0.0228 and 0.0131 . These values indicated that the average of the values of calibration of the Jamar ${ }^{\circledast}$ minus the average of the values of the Takei ${ }^{\circledR}$ dynamometer was -0.0049 with $95 \%$ CI -0.0228 and 0.0131 . On the other hand, there were significant differences between the transducer and each of the other dynamometers.

Even with the sample size calculation indicating the need for 16 participants, 18 healthy volunteers were included to prevent possible effects of drop outs. The 18 volunteers had average age of $20 \pm 1.3$ years, with eight males with weight and height of $73.9 \pm 11 \mathrm{~kg}$ and $1.72 \pm 0.05 \mathrm{~m}$ ) and ten females with weight and height of $60.1 \pm 7 \mathrm{~kg}$ and $1.64 \pm 0.03 \mathrm{~m}$.

The results demonstrated acceptable values of intraclass correlation coefficients between the measures of the three dynamometers both for the female group, ICC $=0.871$ (95\%CI: 0.622 to 0.965 ) for the dominant and ICC $=0.847$ (95\%CI: 0.551 to 0.959 ) for the non-dominant arms, and for the male group ICC $=0.886$ (95\%CI: 0.616 to 0.975 ) for the dominant and ICC $=0.896$ (95\%CI: 0.648 to 0.977 ) for the non-dominant arms.

Figure 4 shows the comparison of measures of force among the three dynamometers, as well as the comparison between dominant and non-dominant limbs.
All volunteers were right handed. Significant differences were found $(\mathrm{p}<0.05)$ in the values obtained with the Takei ${ }^{\circledR}$ $(p<0.001$ and $p=0.022$, female and male, respectively) and the Transducer $(\mathrm{p}<0.001$ and $\mathrm{p}=0.007$, female and male, respectively) when compared with the Jamar ${ }^{\circledR}$ dynamometer. However, the Takei ${ }^{\circledR}$ dynamometer and the Transducer were similar for both female $(\mathrm{p}=0.161)$ and males $(\mathrm{p}=0.850)$. The arm factor also showed significant difference between female $(\mathrm{p}<0.001)$ and males $(\mathrm{p}=0.010)$.

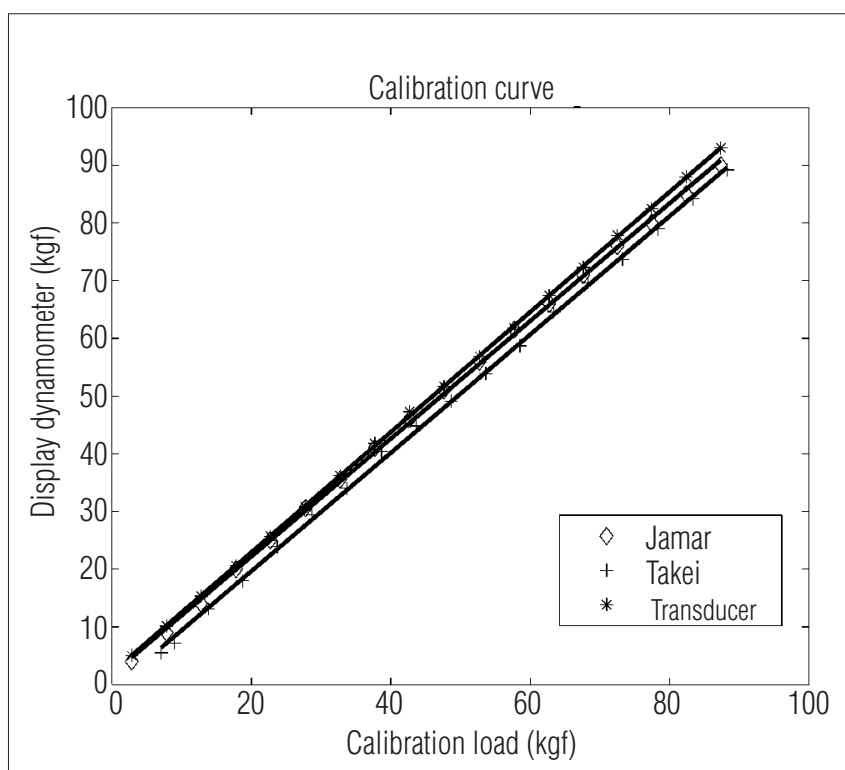

Figure 3. Calibration curves of the Jamar ${ }^{\circledR}$ dynamometer, Take ${ }^{\circledR}{ }^{\circledR}$ dynamometer and the EMG System Manual Transducer for the range of 0 to $90 \mathrm{kgf}$, respecting their maximum scale of $V F E_{\text {jamar }}=90 \mathrm{kgf}, V F E_{\text {takei }}=100 \mathrm{kgf}_{\text {and }} \mathrm{VFE} \mathrm{E}_{\text {transducer }}=200 \mathrm{kgf}$.
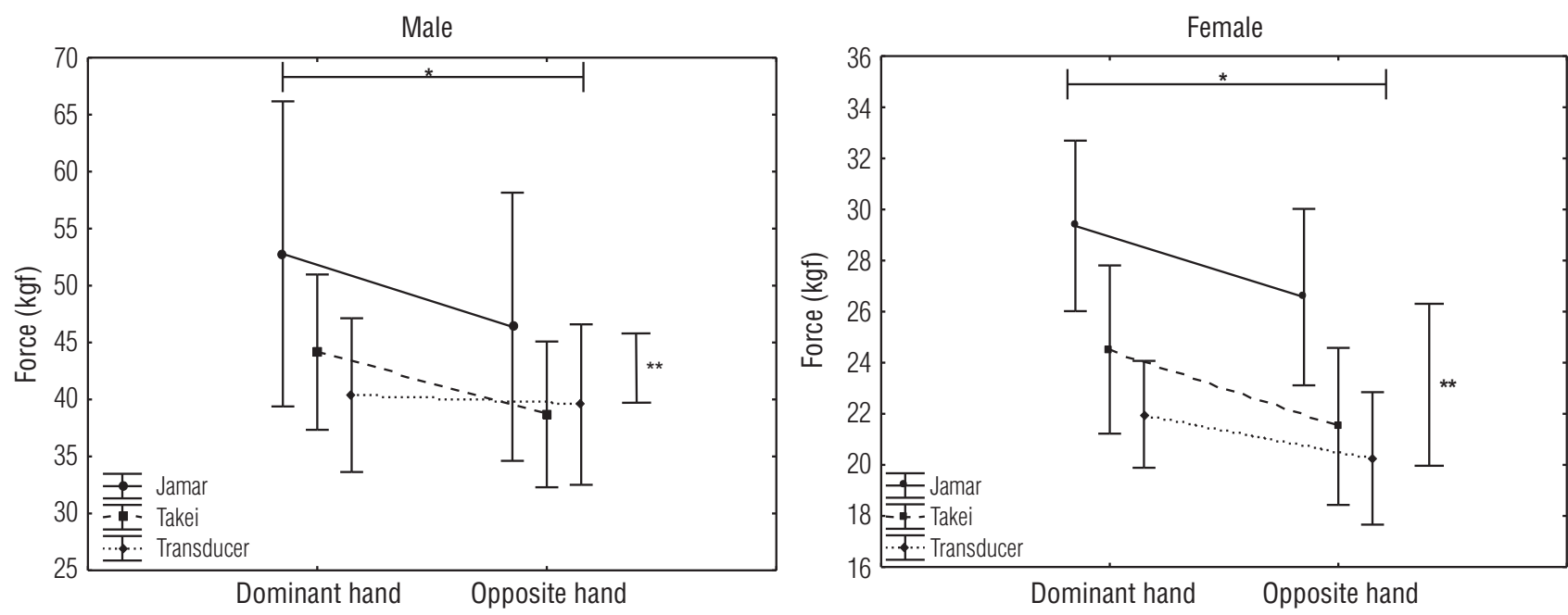

*Significant difference between arms with $p<0.05$; ${ }^{\star *}$ Significant difference between the Jamar ${ }^{\circledR}$ dynamometer with the dynamometers Takei ${ }^{\circledR}$ and Transducer $p<0.05$.

Figure 4. Comparison between the Jamar ${ }^{\circledR}$ dynamometer, the Takei ${ }^{\circledR}$ dynamometer and the EMG System Manual Transducer for the dominant and non dominant sides and female and males. 
The level of agreement between the measurements of the three dynamometers $\left(\right.$ Jamar $^{\circledR}$-Takei ${ }^{\circledR}$, Jamar ${ }^{\circledR}$-Transducer and Takei ${ }^{\circledR}$-Transducer) was tested using Bland and Altman plots. The plots of percentage differences between the dynamometers can be observed in Figure 5 where continuous lines represent average difference and dotted lines represent CI95\%.

\section{Discussion $: \therefore$.}

The present study had proposed to compare the accuracy and precision of measures of grip strength of three dynamometers: the Jamar ${ }^{\circledR}$, Takei ${ }^{\circledR}$ and EMG System Manual Transducer of Brazil. The calibration testing of the dynamometers was conducted for two main reasons: to observe the linearity of responses and to possibly correct if needed the grip strength values obtained. This calibration allowed for an accurate comparison between the strength values obtained with each dynamometer. Calibration procedures have not been noted in earlier studies. Linearity of calibration curves showed that the three equipments preserved the mechanical characteristics from fabrication, without distortions. The angular coefficient of the regression equations were found to be statistically similar only between the

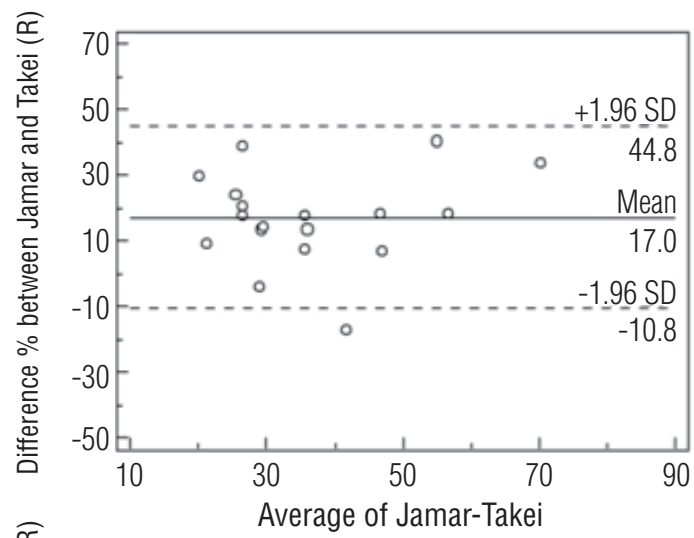

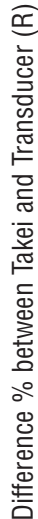

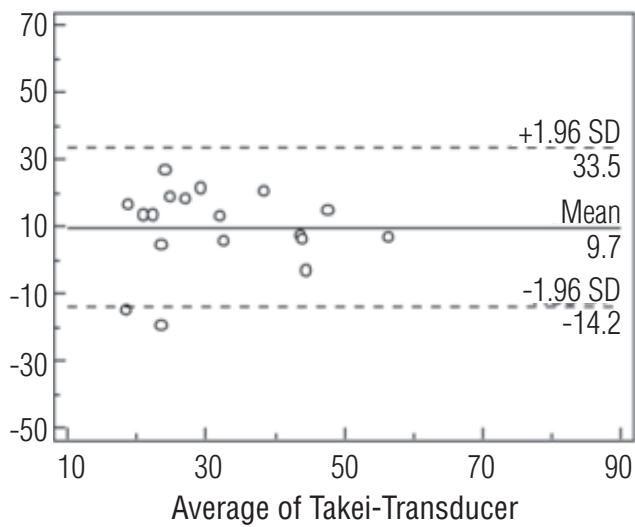

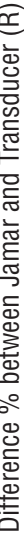
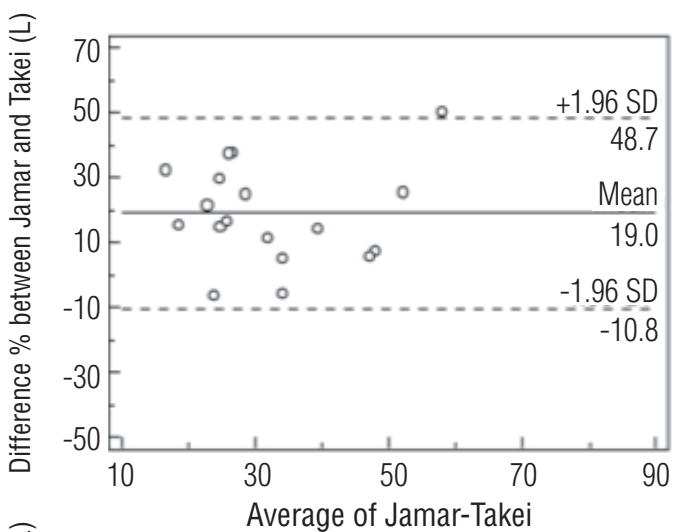

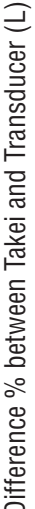

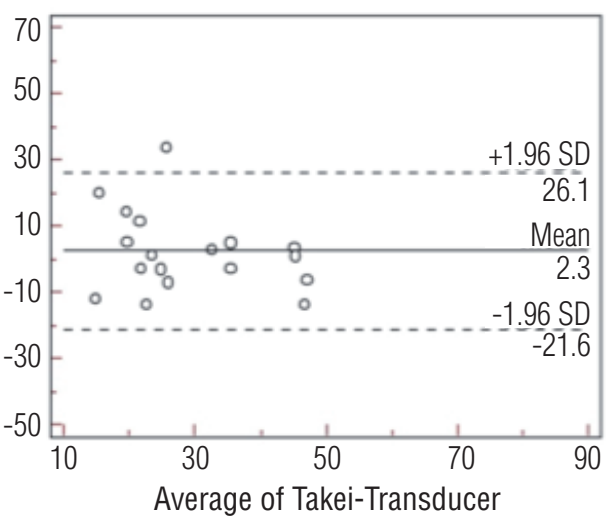

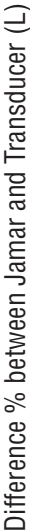

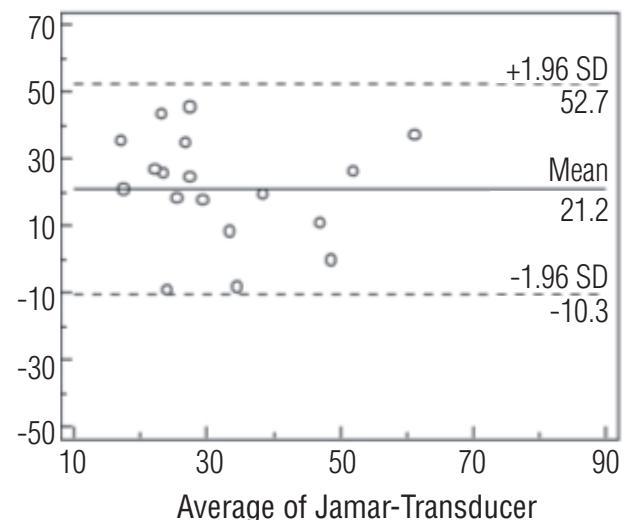

Figure 5. Limits of agreement of Bland-Altman plots between the force values measured by the dynamometers. 
dynamometers Jamar ${ }^{\circledR}$ and Takei ${ }^{\circledR}$. However, the positive values of the mean errors $\left(\mathrm{Jamar}^{\circledR}=2.694 \mathrm{kgf}\right.$; Takei $^{\circledR}=0.306 \mathrm{kgf}$ and Transducer=3.949 kgf) confirmed that the dynamometers indicated, on average, more than the calibration load, as verified on the differences between the linear coefficients of the regression equations. For this reason, the data originally recorded during the tests had to be corrected, ensuring a reliable comparison between individuals grip strength.

The three dynamometers used had shown hysteresis in acceptable levels of $0.23 \%, 0.12 \%$ and $0.33 \%$ of values of full scale (VFS) for the Jamar ${ }^{\circledR}$, Takei ${ }^{\circledR}$ and the Transducer respectively. The usefulness of these measures of hysteresis are important when considering conditions where measurements in both directions are needed such as in the study of relaxation of force at the end of a muscle stress tests in patients with myotonia ${ }^{38}$.

In this study, a statistically significant difference between the dynamometers Jamar $^{\circledR}$ and Takei $^{\circledR}$ and Transducer was observed. The Jamar ${ }^{\circledR}$ presented average values of manual grip strength higher than the values found for the other instruments, both for the dominant and for the non-dominant arms and in both genders. However, the Takei ${ }^{\circledR}$ and theTransducer proved to produce similar results in the sample studied.

In other studies, the dynamometer Jamar ${ }^{\circledR}$ also recorded values of grip strength higher than those of other dynamometers. Massy-Westropp et al. ${ }^{16}$ conducted a study comparing the measurement of palmar grip strength in normal adults, with the hydraulic dynamometer Jamar ${ }^{\circledR}$ and the electronic dynamometer Grippit ${ }^{\circledR}$. The results suggested that the electronic dynamometer Grippit detected smaller variances in strength in relation to the Jamar ${ }^{\circledR}$ hydraulic dynamometer, being therefore more indicated in cases of abnormalities such as arthritis rheumatoid.

Shechtman, Gestewitz and Kimble ${ }^{23}$, analyzing the reliability and validity of the digital dynamometer DynEx in relation to dynamometer Jamar ${ }^{\circledR}$ in 100 individuals between the ages of 20 and 40 years, found significant differences between the instruments, although with a high correlation ( $r>0.98)$. In the study, the dynamometer Jamar ${ }^{\circledR}$ exhibited strength values higher than the digital dynamometer.

Kurillo, Zupan and Bajd ${ }^{22}$ compared the assessment of grip strength with the use of various equipment based on force transducers that resembled objects used in everyday life, on 20 patients with neuromuscular diseases and nine healthy individuals. It was suggested that, although the conventional tests are valid methods for the detection of pathologies, they aren't sensitive to small changes that can serve as indicators of the development of the clinical picture of the disease. For this reason, the authors suggested that instruments with greater precision to perform these evaluations are necessary.
In this study, the dynamometers analyzed showed acceptable values of intraclass correlation coefficient (ICC>0.8). However, Bland and Altmann ${ }^{37}$ plots presented in Figure 5 demonstrated poor agreement between the measures of the dynamometer Jamar ${ }^{\circledR}$ with the dynamometers Takei ${ }^{\circledR}$ and with theTransducer for both limbs. The plots also showed a tendency to increase the difference between measures with the increase in strength. The dynamometers Takei ${ }^{\circledR}$ and Transducer had greater agreement. It is important to note that the quality of the measurements during testing of grip strength was ensured not only by the calibration procedures but the use of trained examiners. The ICCs of grip strength for the dominant and non-dominant hands was the same in both gender.

The differences between instruments may be related to the different means of transmission to measure grip strength (mechanical, hydraulic and electric), in addition to the different shapes of the handles. Mathiowetz ${ }^{20}$ conducted a study with 30 men and 30 women, between 20 and 50 years, comparing the hydraulic Jamar ${ }^{\circledR}$ and Rolyan ${ }^{\circledR}$ dynamometers and found no significant difference between them. According to him, the instruments are equivalent and can be used interchangeably.

However, in spite of the equipments used in this study being different, the measurements can be considered equivalent, since similarity was verified between their respective calibration curves, considering that the calibration load was the same for all three dynamometers, regardless of their mechanical characteristic such as operating principles and processing of ongoing and outgoing signals. For this reason, the equipment is designed, specifically, to the measurement of manual grip strength. On the other hand, the conformation of the hand when involving each handle defines the level of effort to be registered because the shape of the handles sets up the placement of the interphalangeal joints and the metacarpophalangeal joints and thus eliciting a different muscular effort for each situation.

The handle of the dynamometer Jamar ${ }^{\circledR}$, as well as the modified version, have anatomic shape, supporting the thenar eminence in the posterior part and presenting an anterior anatomic configuration. However, the Takei ${ }^{\circledR}$ dynamometer handle has a rectified profile and does not respect the natural accommodation of the hand. Moreover, the modified handle creates a better positioning, allowing greater participation of the fourth and fifth fingers. In the dynamometer Jamar ${ }^{\circledR}$ the fingers gather together more centrally, allowing a greater generation of force.

Regarding the comparison of the handles of the dynamometers used in this study, we were not able to find in the literature, studies that objectively compared the profiles cited. Nevertheless, inferences can be made in relation to the hand position in the different handle profiles. Since the action of the fifth finger was 
maintained in all dynamometers, it was observed that, in the rectified handle of the Takei ${ }^{\circledR}$, the $2^{\text {nd }}, 3^{\text {rd }}$ e $4^{\text {th }}$ showed slight flexion of the metacarpophalangeal joints, indicating excessive action of the intrinsic musculature of the hand. This excessive action of the intrinsic muscles are minimized on the Jamar ${ }^{\circledR}$ dynamometer and the Transducer due to the non-rectified shape of its handle. Because of this, it was expected that the values of strength would be greater for the Take ${ }^{\circledR}$ equipment, which did not occur. In part, this is due to the complacency of the Takei ${ }^{\circledR}$ handle that under load moves, promoting a dynamic effort. On the other hand, the lower strength values measured by the Transducer were justified because of the profile of the anterior aspect of its handle, which promotes static force, keeping the metacarpophalangeal joints in a neutral position during testing, minimizing the action of intrinsic muscles of the hand.

The different characteristics of the dynamometers used in this study demonstrate the need to perform a careful comparison between them. The main limitation of this research was the sample size, although the sample calculation indicated $n=16$. Therefore, further studies, with different samples and methodologies, using, for example, electromyography, could elucidate the effective participation of the fingers in relation to their position according to the profile of the handles and help understand the differences found between these instruments. Although further studies are needed with different samples that may confirm our findings, our results show that the dynamometer Jamar ${ }^{\circledR}$ cannot be used interchangeably with the dynamometers Takei ${ }^{\circledR}$ and Transducer since they produce dissimilar values. In analyses of performance, especially in clinical practice, one has to consider that the shape of the handle will set the performance level of grip strength in isometric stress tests.

The clinical use of these dynamometers should be criteriously, considered, mainly, the need for static calibration prior to isometric stress tests. In addition to the calibration, as an inherent factor in the proper use of measuring instruments, a standardized protocol, such as the one used in this study can improve not only the extent of grip strength, but also the accuracy of measures, enabling future comparisons between different populations or different physio-pathological conditions. In addition, it is important to highlight the level of investment required for each of the types of dynamometers presented here: the Jamar ${ }^{\circledR}$ and Take ${ }^{\circledR}$ are portable and about 1/3 less expensive that the EMG Transducer System, which is computerized and has a calibration system that can be adjusted during use but require technical assistance. The first two are more suitable for the tests to be carried out in clinical practice or even in the ambulatory environment with large numbers of people. However, the Transducer provides graphic visualization and continuous records of grip strength during the tests that can be used in other types of analysis. Additionally, the shape of the modified handle inserted in the Transducer makes it possible for the hand to conform to its grip aligning all medial and distal phalanges to the medium and large sizes of the handle respectively. Clinically, such a configuration makes it possible to highlight the action of the extrinsic muscles of the hand, both for the superficial flexors of the fingers (that insert into the medial phalanges) and for the deep flexors of the fingers (that insert into the distal phalanges).

\section{Conclusion $: \therefore$.}

The results of this study suggest that the values of manual grip strength measured with the Takei ${ }^{\circledR}$ and Transducer instruments are different than the values for the dynamometer Jamar $^{\circledR}$. The dynamometers Takei ${ }^{\circledR}$ and Transducer demonstrated similar grip strength in the sample studied. The influence of the formats of handles on the measurement of grip strength was noted as well as the need for prior calibration of this type of instrument.

\section{Acknowledgements : :}

The present study had financial support from FAPEMIG, which enabled the acquisition of the license of Matlab ${ }^{\circledR}$ software through the project APQ 01284/09.

\section{References}

1. Lauretani F, Russo CR, Bandinelli S, Bartali B, Cavazzini C, Di lorio A, et al. Age-associated changes in skeletal muscles and their effect on mobility: an operational diagnosis of sarcopenia. J App Physiol. 2003;95(5):1851-60

2. van der Schaaf M, Dettling DS, Beelen A, Lucas C, Dongelmans DA, Nollet F. Poor functional status immediately after discharge from an intensive care unit. Disabil Rehabil. 2008;30(23):1812-8.

3. Watanabe K, Tsubota S, Chin G, Aoki M. Differences in parameters of the explosive grip force test between young and older women. J Gerontol A Biol Sci Med Sci. 2011;66(5):554-8.

4. Edwards SG, Johansen JA. Prospective outcomes and associations of wrist ganglion cysts resected arthroscopically. J Hand Surg Am. 2009;34(3):395-400.
5. Lucado AM, Li Z, Russell GB, Papadonikolakis A, Ruch DS. Changes in Impairment and function after static progressive splinting for stiffness after distal radius fracture. J Hand Ther 2008;21(4):319-25

6. Rogers MW, Wilder FV. Exercise and hand osteoarthritis symptomatology: a controlled crossover trial. J Hand Ther. 2009;22(1):10-8.

7. Schreuders TA, Roebroeck ME, Jaquet JB, Hovius SE, Stam HJ. Measuring the strength of the intrinsic muscles of the hand in patients with ulnar and median nerve injuries: reliability of the Rotterdam Intrinsic Hand Myometer (RIHM). J Hand Surg Am. 2004;29(2):318-24.

8. Moreira D, Álvarez RRA, Gogoy JR, Cambraia AN. Abordagem sobre preensão palmar utilizando 0 dinamômetro JAMAR ${ }^{\circledR}$ : uma revisão de literatura. Rev Bras Ciênc Mov. 2003;11(2):95-9. 
9. Bohannon RW. Hand-grip dynamometry predicts future outcomes in aging adults. J Geriatr Phys Ther. 2008;31(1):3-10.

10. Figueiredo IM, Sampaio RF, Mancini MC, Nascimento MC. Ganhos funcionais e sua relação com os componentes de função em trabalhadores com lesão de mão. Rev Bras Fisioter. 2006;10(4):421-7.

11. Ashton L, Myers S. Serial grip strength testing - Is role in assessment of wrist and hand disability. The Internet Journal of Surgery. 2004;5(2).

12. Bertuzzi RCM, Franchini E, Kiss MAPD. Análise da força e da resistência de preensão manual e as suas relações com variáveis antropométricas em escaladores esportivos. Rev Bras Ciênc Mov. 2005;13(1):87-93

13. Leyk D, Gorges W, Ridder D, Wunderlich M, Rüther T, Sievert A, et al. Hand-grip strength of young men, women and highly trained female athletes. Eur J Appl Physiol. 2007;99(4):415-21.

14. Borges Júnior NG, Domenech SC, Silva ACK, Dias JA, Sagawa Júnior SY. Estudo comparativo da força de preensão isométrica máxima em diferentes modalidades esportivas. Rev Bras Cineantropom Desempenho Hum. 2009;11(3):292-8.

15. Josty IC, Tyler MPH, Shewell PC, Roberts AH. Grip and pinch strength variations in different types of workers. J Hand Surg Br. 1997;22(2):266-9.

16. Massy-Westropp N, Rankin W, Ahern M, Krishnan J, Hearn TC. Measuring grip strength in normal adults: reference ranges and a comparison of electronic and hydraulic instruments. J Hand Surg Am. 2004;29(3):514-9.

17. Dias JA, Ovando AC, Külkamp W, Borges Júnior NG. Força de preensão palmar: métodos de avaliação e fatores que influenciam a medida. Rev Bras Cineantropom Desempenho Hum. 2010;12(3):209-16.

18. Fess E. Grip strength. In: Casanova JS. Clinical assessment recommendations. $2^{\text {nd }}$ ed. Chicago: American Society of Hand Therapists; 1992. p. 41-45.

19. Weinstock-Zlotnick G, Bear-Lehman J, Yu TY. A test case: does the availability of visual feedback impact grip strength scores when using a digital dynamometer? J Hand Ther. 2011;24(3):266-76.

20. Mathiowetz $\mathrm{V}$. Comparison of Rolyan and Jamar dynamometers for measuring grip strength. Occup Ther Int. 2002;9(3):201-9.

21. Shechtman 0 , Davenport $R$, Malcolm M, Nabavi D. Reliability and validity of the BTE-Primus grip tool. J Hand Ther. 2003;16(1):36-42.

22. Kurillo G, Zupan A, Bajd T. Force tracking system for the assessment of grip force control in patients with neuromuscular diseases. Clin Biomech (Bristol, Avon). 2004;19(10):1014-21.

23. Shechtman 0 , Gestewitz L, Kimble C. Reliability and validity of the DynEx dynamometer. J Hand Ther. 2005;18(3):339-47.
24. Svens B, Lee H. Intra- and inter-instrument reliability of Grip-Strength Measurements: GripTrack ${ }^{\mathrm{TM}}$ and Jamar ${ }^{\circledR}$ hand dynamometers. Hand Ther. 2005;10(2):47-55.

25. Cardoso JR, Azevedo NCT, Cassano CS, Kawano MM, Âmbar G. Confiabilidade intra e interobservador da análise cinemática angular do quadril durante 0 teste sentar e alcançar para mensurar o comprimento dos isquiotibiais em estudantes universitários. Rev Bras Fisioter. 2007;11(2):133-8.

26. Novo Júnior J, inventor; Universidade Federal de Juiz de Fora, cessionário. Configuração aplicada em empunhadura. Brasil patente DI 6901797-2. 2009 mai 05.

27. Novo Júnior J, Martins LEB, Cliquet Júnior A, Gallo Júnior L. A force-pressure interface for muscle strength evaluation. Rev Bras Eng Bioméd. 2000;16(1):3-11.

28. Novo Júnior JM. Preliminary study of design and sizing of ergonomic handle for hand dynamometers. In: $1^{\text {a }}$ Jornada de Ergonomia da UFJF; 2003; Juiz de Fora. $1^{\text {a }}$ Jornada de Ergonomia da UFJF; 2003.

29. Essex-Sorlie D. Medical biostatistics \& epidemiology. Examination \& board review Norwalk: Appleton \& Lange (a LANGE medical book); 1995.

30. Fonseca JS, Martins GA. Curso de estatística. 6ª ed. São Paulo: Atlas; 2006.

31. Fess E. A method for checking Jamar dynamometer calibration. J Hand Ther. 1987;1(1):28-32.

32. Rolyan SP. Hydraulic Hand Dynamometer Owner's Manual. $1^{a}$ ed. Nottinghamshire: Sammons Preston Rolyan; 2003.

33. Bowman $P$, Johnson L, Chiapetta A, Mitchell A, Belusko E. The clinical impact of the presence or absence of the fifth finger flexor digitorum superficialis on grip strength. $J$ Hand Ther. 2003;16(3):245-8.

34. MacLennan RN. Interrater Reliability with SPSS for Windows 5.0. The American Statistician 1993;47(4):292-6.

35. Looney MA. When is the intraclass correlation coefficient misleading? Meas Phys Educ Exerc Sci. 2000;4(2):73-8.

36. Weir JP. Quantifying test-retest reliability using the intraclass correlation coefficient and the SEM Strength Cond Res. 2005;19(1):231-40.

37. Bland JM, Altman DG. Statistical methods for assessing agreement between two methods of clinical measurement. Lancet. 1986;1(8476):307-10.

38. Hogrel JY. Quantitative myotonia assessment using force relaxation curve modelling. Physio Meas. 2009;30(7):719-27.

39. Doebelin E 0. Measurement systems: application and design. $5^{\text {th }}$ ed. New York: McGraw-Hil Book; 2004. 